\title{
Salt Fish and Molasses: Unsettling the Palate in the Spaces Between Two Continents
}

\author{
Gina Snooks \\ Department of Women's Studies and Feminist Research and Centre for \\ Transitional Justice and Post-Conflict Reconstruction, Western University \\ Sonja Boon \\ Department of Gender Studies, Memorial University
}

Food stories play an integral role in the ways that we imagine ourselves, both intimately in the context of home and family, and politically, in the context of the nation-state. But while food is intricately woven into the politics of place, it also crosses boundaries, gaining new meanings in the process. In this paper, we consider the transnational food histories that link the geographically distant but colonially-linked regions of Newfoundland and Suriname. Our collaborative autoethnographic inquiry examines the role that salt fish and molasses have played in our respective bodily memories and experiences. Central to our inquiry is a single question: What happens when salt fish-Newfoundland's greatest export product-meets molasses, the sticky treacly by-product of the colonial Caribbean's sugar cane refining process; that is, what happens when our palates meet? Engaging a decolonial lens, our collaborative work suggests the necessity of moving beyond culinary nostalgia towards the complexity of an 'unsettled palate' that acknowledges the legacies of our shared transnational histories and the ongoing effects of colonialism and slavery. In the process, we critically reflect upon the ways in which we are each implicated in these histories, albeit in different ways.

Keywords: recipes; decoloniality; autoethnography; embodied memory 


\section{PROLOGUE}

Along the east coast of what is now known as Canada, the land and sea hold the stories of my ancestors - tales about where I come from and, dare I say, to whom I belong. Here my footprints trace the same rugged shorelines and rocky beaches upon which my ancestors have walked for centuries; here my footsteps follow those of my grandmothers and their mothers and their mothers before them. As I trace the footsteps of my ancestors, both theoretically and in a material sense, it occurs to me that my own footsteps perform a kind of embodied testimony; my footprints are a testament to our shared stories.

Perhaps my Indigenous ancestors knew this land as K'taqmkuk, a Mi'kmaq word that translates into English as 'the land across the water' (K'Taqmkuk Mi'kmaw). My ancestors who came from Ireland, however, may have known this place as Talamh an Eisc, which translates as land of fish. To the English, though, this island in the North Atlantic Ocean was the New Founde Land. My European ancestors came, I suppose, for the fish, persuaded, I imagine, by sailors' tales of waters so rich with cod fish that baskets could be used to scoop the fish into boats. In truth, I cannot say what drew my ancestors to settle upon this island. What I can say for certain, however, is that for roughly five centuries the island of Newfoundland ${ }^{1}$ had been known worldwide for its cod fishing industry and that my own family histories are inextricably entwined within those broader narratives. (Gina)

\section{INTRODUCTION}

Food stories play an integral role in the ways that we imagine ourselves, both intimately in the context of home and family, and politically, in the context of the nation-state. But while food is intricately woven into the politics of place, it also crosses boundaries, gaining new meanings in the process. In this paper, we consider the transnational histories that emerge in the relationships between the geographically distant but coloniallylinked regions of Newfoundland and Suriname, looking at how food production in these two regions subsequently shaped local palates and cultural identities. Drawing on memory work, the "conscious and purposeful staging of memory" (Kuhn 2010, 303; see also Chang 2008; Till 2008) and observational work, and situating our analysis within the context of food studies scholarship, we focus on two food products: salt fish and molasses. Salt fish-a key product of Newfoundland's outport local economies and central to understandings of gendered bodily laborbecame a staple element of West Indian slave and Creole diets. Molasses, meanwhile, produced in giant vats on West Indian plantations, became an integral element of Newfoundland culinary identity. 
This paper emerges out of a collaborative autoethnographic inquiry through which each of us interrogated our palate, considering the role that salt fish and molasses have played in our respective embodied memories and experiences. Central to our inquiry is a single question: What happens when salt fish-Newfoundland's greatest export product-meets molasses, the sticky treacly by-product of the colonial Caribbean's sugar cane refining process? In other words, what happens when our palates meet? Engaging a decolonial lens, our collaborative work suggests the necessity of moving beyond culinary nostalgia towards the complexity of an 'unsettled palate' that acknowledges the legacies of our shared transnational histories and the ongoing effects of colonialism and the afterlives of transatlantic slavery. In the process, we critically reflect upon the ways in which we are each implicated in these histories, albeit in different ways.

\section{AUTOETHNOGRAPHY FROM 'ME' TO 'WE'}

An "insider" approach (Anderson 2006; Ellis 2003; Islam 2008; Muncey 2010), autoethnography places researcher subjectivity at the heart of the research process (Anderson 2006; Ellis 1999, 2003; Muncey 2010; Spry 2001, 2011; Wall 2008). But while the personal is central to autoethnographic work, it is not the end goal (Behar 1996; Chang, Wambura and Hernandez 2013). Rather, autoethnography brings the autobiographical self into conversation with theory, producing texts and performances that integrate the personal, the social and the political (Reed-Danahay 1997; Spry 2011; Tsalach 2013). As Wall (2008) has observed, "individuals do not exist outside their social context" (49; see also Pathak 2013, 595).

This imbrication of the self within the social, and of the social within the theoretical, has informed our work here. Building on Paul John Eakin's observation that "all identity is relational" (1999, 43-4), we undertake a dual task. As collaborative autoethnographers, we locate ourselves firmly inside our research, as embodied, feeling, thinking research subjects (Spry 2001). But we also simultaneously situate ourselves as scholars of autobiography and life writing, researchers who turn critical lenses to our autoethnographic work. In this entangled relationship, the self emerges as both research subject and critical analyst, a process that allows us to think and write both critically and intimately. As Vinh Nguyen (2015) has argued, "[w] riting intimately is—has to be-critical. Writing critically has to be intimate" (472). Like Nguyen, we seek to "write in a critical manner that is attached, embodied, and felt" so that we can use our very selves to "facilitate criticality" (472). ${ }^{2}$ 
In this way, we bring autoethnography and life writing into conversation with one another, considering how it is that each intersects with, challenges, and extends the other. Like Smith and Watson's (1996) bricoleur who "takes up bits and pieces of the identity and narrative forms available and, by disjoining and joining them in excessive ways, creates a history of the subject at a precise point in time and space" (14; italics original), we are methodological magpies who scavenge our way through our project (Halberstam 1998, 13), using our dual positioning as researchers and research subjects to interrogate our pasts and our presents. In this space, "we move in and out of autobiographical subjectivity" (Smith and Watson 1996, 17), at once agents and critics of our life writings.

We understand life writing as an umbrella term that encompasses diverse genres including: cookbooks, memoirs, diaries and even Facebook posts, blogs and so forth through which "individuals commit to auto/biographical acts”, as Ricia Anne Chansky writes (xxi). Women's auto/biographies, as we demonstrate, are media through which we might critically engage with feminist, postcolonial (Smith and Watson 1998, 5) and decolonial theories.

More recently, autoethnographers have begun working collaboratively, developing an approach that emerges from shared histories, experiences, and social locations (Chang, Wambura and Hernandez 2013; Diversi and Moreira 2016; Holman-Jones, Adams and Ellis 2013), which allows for the interrogation of multiple subjectivities within a single autoethnographic framework (Alexander, Moreira and kumar 2012; Moreira 2009). In our collaborative approach, we unsettle the autoethnographic 'I' by focusing on 'we' (Spry 2016, ch. 2) —not just the 'we' of our joint writing, but a 'we' that connects our food stories to longer histories, a 'we' that locates our stories within transnational encounters. The 'we' of this narrative is not a comfortable 'we'; rather it is a 'we' embedded within the messy politics and uncomfortable logics of colonialism as these have shaped our personal histories, our conversations, our palates, and our selves. Our food stories, then, not only tell stories of colonialism and empire, but also work to disrupt their effects.

\section{A COLLABORATIVE PROCESS}

Our collaborative autoethnographic approach has engaged several distinct modes of inquiry (Chang 2008), among them memory work, nonparticipant observation, archival research, and critical conversations. It is difficult to pinpoint precisely when and where we first began to discuss the interconnectedness of our seemingly diverse personal and cultural 
histories and foodways. Gina began thinking about the relationship between salt fish and molasses while conducting research for a term paper for an undergraduate course in feminist research methods for which Sonja was her instructor. Perhaps it was then that the seeds for this shared dialogue were planted. However, the connections between our shared histories became more evident a few years later, when we began working together on a project that considered transnational migration and transnational identity.

The core of the work for this essay emerged during an intensive eightday period of fieldwork in Paramaribo, Suriname in February 2015. Moving both together and separately through this environment, we maintained separate reflexive research journals and met for between one and two hours daily to discuss our observations. In addition to this, we both undertook archival research, before, during, and after our trip, to uncover the possible links between Newfoundland and the West Indies, consider food histories, and explore historical migrations of products and peoples. Our critical conversations continued-via email and Skypeover the next two years, after our return to Canada. We maintained our individual reflexive journaling throughout this time.

As we explored further thoughts and ideas about migrations, memories, and belonging, we started to consider our shared and disparate culinary histories born of the realities of global trade circuits. Gina's family histories traverse the island of Newfoundland; Sonja's meanwhile, stretch to include a lineage that unites European imperialism with transatlantic slavery, histories of indenture, and new world creolization. And yet, these global trade networks have ensured that our food histories, seemingly so disparate, can never be disentangled from one another. Just as salt fish travelled south from Newfoundland to the West Indies, so, too, did molasses travel north. Family recipes-personal archival materials located within rich family oral histories-became particularly relevant vehicles for exploring the relationships between the intimate and the political, the local and the global (Theophano 2002). As primary sources, these documents facilitated our autoethnographic reflections (Chang 2008, 107).

In this essay, we theorize not only through our interrogation of the recipes that shaped our experiences (Tye 2010), but also through the shared critical conversations that structure our encounters with these foods; that is, with the shared and disparate meanings that we have attached to palate and place. Our life stories, as Elyse Pineau puts it, "have rubbed up against one another". (qtd. in Spry 2016, 66); meaning, as a result, emerges at the point of their encounter.

We each focus on two recipes, one each for molasses and salt cod. Our collaborative autoethnographic approach allows us to move beyond 
understandings of food and foodmaking as important sites of nostalgia and belonging in local contexts towards critical engagements with food and foodmaking as sites of transnational meaning-making. Our work suggests that food and food stories must be understood within the context of what Lisa Lowe (2015) terms the "intimacies of four continents". More specifically, we argue that a transnational and decolonial frame can unsettle and disrupt the palate.

In simple terms, decolonization is an act of "undoing colonialism" (Wallace 2013, 14). Decolonizing research practices thus "demand a critical reflexive lens that acknowledges policies of representation" (Kovach 2009, 33), particularly those policies that are inseparable from the politics of colonialism and imperialism (see also Smith 2012). Eve Tuck and K. Wayne Yang remind us that decolonization is uncomfortable, uneasy, and fundamentally unsettling $(2012,3)$. It is never innocent. Eve Tuck and C. Ree (2013) link the practice of decolonization with haunting. Drawing on the earlier work of Avery Gordon, they argue that " $[\mathrm{h}]$ aunting is the cost of subjugation. It is the price paid for violence, for genocide" (643). To be haunted, in other words, is to live with discomfort and disruption, to acknowledge active presence of the ghosts of colonial violence. As they observe, "Decolonization must mean attending to ghosts, and arresting widespread denial of the violence done to them" (647). To unsettle the palate is, we argue, to acknowledge and claim the complexities embedded in the foods that we consume. It is to integrate colonial violence into the intimate nostalgia and longing that we associate with food.

How long does it take before cane syrup becomes molasses? How do you know when the salt fish is done? Can you measure this in time, or is that knowledge only in your body? What happens when a Newfoundlander eats Caribbean molasses? Or when a Caribbean person snacks on salt fish? Can bodily memory travel across time and space? (Sonja)

\section{COOKBOOKS AND IDENTITY MAKING}

Recipes, Diane Tye observes, can be understood as forms of "everyday autobiography" (Tye 2010, 32; see also Smith and Watson 1996); within them, one can read not only the ingredients for a particular dish, but also, the ingredients for a life. Gathered into larger cookbooks, recipes can take on broader social and political meaning. Janet Theophano, who has studied a range of historical and contemporary women-authored cookbooks-both in published and manuscript form-contends that "cookbooks are forums for discussing the conduct of life. Even the most pragmatic of cookbooks alludes to both a moral world and an aesthetic to 
be tended" (Theophano 2002, 227). They are, as Rosalyn Collings Eves (2005) observes, "memory texts" infused with affective meanings. So, too, have cookbooks been intimately linked with questions of national identity (Folch 2008; Wilk and Barbosa 2012). "Cooking", David Sutton (2001) argues, "is not simply an everyday practice, but an attempt to reconstruct and remember synaesthetically, to return to that whole world of home, which is subjectivity experienced both locally and nationally, if not at other levels as well" (86).

As repositories for affective memories (Protschky 2009, 371) and "embodied engagements" (Antoniou 2004), recipes are multi-sensory windows into history, memory, and bodily knowledge (Heldke 1992a,b). As Maria Antoniou observes of her own culinary histories: "Cypriot store cupboard basics: lemon, olive oil, garlic, parsley. The taste of my ethnicity? I imagine that my genes are marinated in this mixture" (127). Antoniou's comments are evocative, suggestive of a bodily memory that transcends time and space. Food, she argues, is something integral to ethnic identity; herbs and spices marinate one's very bodily self.

\section{SALT FISH STORIES}

Sprawled across a page in my research journal, written in what is easily recognizable to me as my mother's handwriting, are the words:

\footnotetext{
Salt fish

Place potatoes on bottom of pot.

Place salt fish on top of potatoes.

Boil until potatoes are cooked.
}

Perhaps my mother would not consider these words to be part of her life story. Nor would she likely think of these instructions as a representation of the ways in which our family foodways are intimately woven within the broader scope of the history of the transatlantic fishing industry and, by extension, colonialism and the transatlantic slave trade. What I can say, however, is that both my mother and my aunt, who happened to have served this dish on the very day my mother wrote in my journal, agree that these simple instructions are all that are required to make a meal of salt fish and potatoes. Equally simple, to add brewis to this dish, the instructions are as follows:

Soak a couple of cakes of Purity hard bread in water for at least three-to-four hours. Strain. Bring to a boil in a small amount of hot water (enough to cover the bottom) in a separate saucepan and place hard bread in for three-to-four minutes. Long enough to steam the brewis. Strain again and serve as a side with salt fish and potatoes. 
Around my aunt's table, these simple dishes might be garnished with a heaping spoonful of melted butter, drawn butter or even ketchup for a contemporary flavor. However, I prefer to top my fish and brewis with molasses, which is a taste I acquired along a different coastline of Newfoundland from my paternal grandmother's kitchen in the Bay of Islands. ${ }^{3}$ (Gina)

In Newfoundland vernacular the term 'fish' implies a species of cod fish that has been harvested for centuries along the shores of Newfoundland and Labrador. In other words, unless otherwise specified, fish is always cod in Newfoundland. Salt fish, following this logic, refers to salted cod. Salt fish has been at the heart of the Newfoundland and Labrador fishing industry since the 1500s (Pope 2008), with British, French, and Basque interests plying the waters around the Grand Banks and taking in, even in the early days, some 200 to 205,000 tonnes of live catch (Pope 2008, 28). As the meal served at Gina's family gathering demonstrates, fish continues to be an important part of Newfoundland and Labrador culinary traditions to this day.

Fisherpeople in small outport communities worked together to, in the words of Hilda Chaulk Murray, "[wrest] a living from the sea and land" (20). According to Murray, in the summers, fishermen would head out early in the morning. The women in the community, rising slightly later, would take on the shore aspects of the fishery. Together, the community worked to catch and 'make'-or process-the fish for market.

Making fish was a profoundly gendered activity (Murray 2010; Porter 1995). Once the fish were washed and cleaned, they were laid outside to dry as part of the curing process. There were often several lots of fish on the go, each at a slightly different stage of the process. The weather, always fickle in Newfoundland, could make or break the fish. And the work itself was hard, back-breaking, and relentless. Women working on the shores had to be attentive to the local environment: temperature, sun, wind, and rain. Any one of these could affect the curing process. Women's bodies were fundamentally shaped by making, by the rhythmic bending, reaching and scooping that marked their daily lives, by the pungent, acrid smell of fish drying on wooden flakes and rocks, by the stickiness of salt air, and hands rubbed raw as a result of their labors.

Salt fish has been inextricably linked to the politics of place in Newfoundland and Labrador, where I trace the footprints of some of my ancestors. Traditionally, these lands were Mi'kmaq and Beothuk ${ }^{4}$ territories. In that respect, I cannot help but wonder what my grandmothers' grandmothers might have thought upon witnessing the arrival of these newcomers whose ships laid anchor in the bays and harbours. I wonder what these women might have thought of the folks whose footsteps, left upon 
the rocky beaches whilst curing their fish, would shape the course of history, perhaps in unimaginable ways. Could these women feel change coming on the winds and, perhaps, sense it in their bones? In truth, I cannot know, particularly since, with the exception of a few traces, found marriage certificates and birth records, very few records of theses women's lives have been preserved.

At a root level, salting fish was about preserving fish in order to make it last. While the process was entirely practical in past generations, today, with refrigeration, the act of salting fish seems to be more about preserving both a way of life and the memories of the past. Foods, David Sutton observes, "are particularly fragrant markers" of origins (2001, 79).

But Newfoundland salt fish stories are not the only salt fish stories. A haunting passage in The History of Mary Prince, a slave narrative first published in 1831, describes the harsh realities of salt production on Grand Turk Island: "Our feet and legs, from standing in the salt water for so many hours, soon became full of dreadful boils, which eat down in some cases to the very bone, afflicting the sufferers with great torment" (Prince 10). Salt, this excerpt suggests, must always be understood as more than a preservative; in the context of Grand Turk's salt ponds, it does quite the opposite. Biting into flesh, salt burns and sears bodies with the marks of slavery and unfreedom. Surinamese Maroon oral history echoes these ideas: bakra salt—white people's salt—was understood to "drain magical powers", which made it impossible for enslaved Africans to return home (Hoogbergen 2008, 23).

\section{BATJAUW/SALT COD: COMPLICATED BELONGINGS}

"Newfoundland?" one of my aunts apparently crowed upon hearing that I'd been offered a position at Memorial University. "That's where the batjauw ${ }^{5}$ comes from!" While archival newspapers suggest that my aunt probably mixed up St. John's, Newfoundland with Saint John, New Brunswick, and while even Saint John is up for debate according to an uncle who said it was Halifax, my aunt was right in stating that there's a long history of salt fish traveling from Newfoundland to the plantations in the Caribbean.

Salt fish is big in my mother's side of the family. Alliances have been made through salt fish: when my husband's parents brought Faroe Islands' salt air-dried fish to our wedding, my Surinamese relatives congregated around it, snacking the night away. It wasn't exactly batjauw, but it was certainly close, and they made the most of $i$. And so it came to be that the palates of widely disparate worlds-Newfoundland, Nova Scotia, New Brunswick, Massachusetts, the Faroe Islands, and Suriname-were united through a single export product. 
Salt fish isn't something that ever figured in my diet as a child. But how could it, really? I spent most of my childhood in land-locked small-town Alberta, Canada. And yet, for my mother and her siblings, salt fish was an experience-a flavor, a history, a memory - they shared. For my Newfoundland neighbors, too, it's part of the palate of identity, a key element of shared stories and histories.

We first tasted Newfoundland salt cod two weeks after our arrival in St. John's in 2008. It was Canada Day and we'd planned a suitably full day of patriotic festivities in this new place we would call home: up to Signal Hill at 5:30 in the morning for the Sunrise Ceremony; to the provincial celebrations in the early afternoon and then back up to Signal Hill again, to close things off.

In the afternoon, Signal Hill was busy with activity. While my older son-then six-learned how to gut fish using a wooden knife and quilted fabric fish guts, we sampled a local chef's Salt Cod in Cream Sauce and were instantly hooked. (Sonja)

The best grade of Newfoundland salt fish was shipped to European markets; the "refuse fish"-lower grade fish refused by Europeans-was shipped to the West Indies "where the Caribbean sugar economy, with its massive slave-labour force, welcomed cheap food imports, even refuse fish" (Janzen 2008, 54). Since this "refuse fish" was both cheap and a good source of protein, it was an ideal food source for plantation owners looking for economical ways to sustain their enslaved workers, the thousands who produced not only sugar, but also its by-products-molasses and rum-for trade in Europe. The enslaved did not enjoy a balanced diet, however. Chronically underfed, and with rations that often consisted only of salt cod and bananas, "many slaves died of starvation and malnutrition" (Vaneker 92).

What we didn't know, on that first Canada Day in Newfoundland, was that for Newfoundlanders, Canada Day is Memorial Day, a day of remembrance to honor the several hundred members of the Royal Newfoundland Regiment who died at the Battle of the Somme on 1 July 1916 (Bannister 2002). Nor did we know that Memorial Day is also, in Suriname, Emancipation Day, a day to honor and celebrate the end of slavery in 1863 (Stipriaan 2004). What we didn't pay attention to, that day so many years ago, was the fact that our salt fish stories were founded on the dispossession and erasure of Indigenous stories, lands, and people. Salt fish moves through all of these events in different ways, linking itself to place and memory through the palate. Food and flavor attach themselves to troubled histories, contested nationalisms, and conceptions of home.

Salt cod in cream sauce is a quintessential Northern European comfort dish imagined through the Newfoundland palate. Buttery and rich, thick with potatoes and 
onions, it evokes cold winter winds and warm family dinners, the cozy warmth of home. But Surinamese salt fish, shaped by long histories of forced and voluntary migration, is very different. My uncle's recipe is as tangy, spicy, and complex as the histories from which it emerged. Sautéed with ginger, garlic, pickled onion, and a Madame Jeannette pepper, this dish gestures towards a creolized palate that has integrated a British pickle with eastern ginger and garlic, and a classic Surinamese hot pepper. Apparently one of the hottest peppers around, the Madame Jeannette pepper got its name from any number of sources: a particularly violent slave owner, a brothel madame, or even a famous urban prostitute. It all depends on which version of the story you want to believe. These are complicated flavors born of complicated migrations.

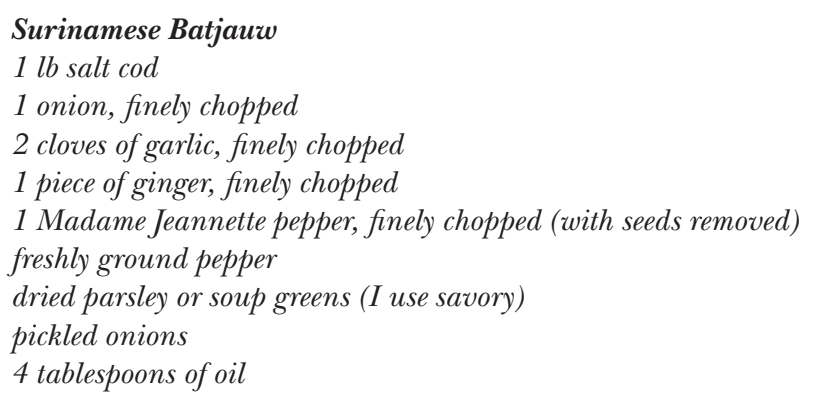

First, soak the fish to release the salt. Dry the fish and flake it. Cook onion, ginger, garlic, Madame Jeannette pepper in oil. Turn heat to high and slowly add flaked salt fish. Cook on low for five minutes. Add half a glass of water and simmer until cooked. Add soup greens and pepper. Add pickled onions. Enjoy with root vegetables or on a bun.

There are very few Surinamese meals that I can cook in Newfoundland; the ingredients are, in many cases, impossible to find. But Surinamese batjauw-made with onion, ginger, garlic, pepper, parsley, pickled onions, a hot pepper, and Newfoundland salt cod, is one thing I can make, in the process bringing memory, identity, and the palate across the Atlantic one more time. (Sonja)

\section{THE STICKINESS OF MOLASSES}

Just as salt fish was sent down to the West Indies as sustenance for the enslaved, so, in return, was molasses loaded onto ships leaving the West Indies and destined for northern waters, where it would provide a cheap source of food for poor fisherfolk along the coasts of Newfoundland. Molasses was an important export product in nineteenth-century Suriname. 
While the Dutch weren't interested in molasses, North Americans were. Between 1816 and 1830 approximately forty-one ships carrying an average annual load of 702,610 gallons of molasses, sailed to ports in North America (Benjamins and Snelleman 346). Even as the sugar economy lost its power, molasses continued to be shipped north. Like cocoa, coffee, and balata - a rubber-like material -it was weighed and measured, the statistics were recorded in the local newspapers. In August 1863, for example, the Dutch schooner, Flying Dutchman, was cleared to transport thirty-six vats—or 5,156 gallons—of molasses to Boston ("Scheepstijdingen" 1863). Another schooner, Breeze, transported ninety-eight vats-13,400 gallonsto Boston in March 1870 ("Scheepstijdingen" 1870).

How might we understand this movement of molasses, its sticky journeying through Atlantic waters? Sara Ahmed writes that "[a]ffect is what sticks, or what sustains or preserves the connection between ideas, values, and objects" $(2010,29)$. Can we understand molasses as an affective substance, capable of binding disparate histories together? Salt fish and molasses stick to our memories, connecting past and present generations of Newfoundlanders and Surinamese peoples whose embodied ways of knowing travel, in the form of salt fish and molasses, across time and space as well as land and sea to end up on the dinner tables of those whose lived realities are intimately connected, even if unbeknownst to each other.

This sticky entanglement of desire, memory, and history is equally evident in molasses stories. Eating molasses buns or baked beans is not simply an act of taking in food to sustain the body but also an act of performing embodied memories. The literal stickiness of molasses can move across generations, gluing people and their stories together. Such stickiness also makes for inadvertent linkages and connections, telling stories not only about the two entities bound up in the molasses, but also about the nature of the encounter itself.

\section{EMBODIED MEMORIES}

My memory goes like this: my mother in the kitchen, puttering about before dinner, because she was the one who always made dinner. Building a salad. Boiling potatoes. Cooking up meatballs, or meat loaf, or chicken, or roast beef. The soundtrack a chorus, on repeat, hummed under her breath or whistled through her teeth: "B.B. met R., dat is bruine bonen met rijst/B.B. with R., that is brown beans with rice".

Beans and rice is a classic Caribbean dish, slightly different in every region. In Jamaica it's made with coconut milk. In Barbuda, pigeon peas marinate together with okra, curry powder, and cornmeal (Berleant 2012). In Guyana, meanwhile, it's a chick pea dish known as "Cookup 
Rice" (Richards-Greaves 2012). In Suriname, it's silky smooth, gently spicy: beans, onions, salt meat, and Chinese long beans flavored with tomato paste, garlic, ginger, hot pepper, and the earthy sweetness of molasses.

I do not recall eating beans and rice at home, nor did we go to any restaurants that served it. It is something that I remember only from our infrequent trips we made to the Netherlands to visit relatives, or, perhaps, some vague recollection from preschool years in South America. But beans and rice have lodged themselves into my memory, sideways, through song. The song's chorus immediately evokes its flavors, bringing up the tangy sweetness of molasses, the zing of fresh ginger, the smell of garlic and the tartness of salt meat. The flavors dance through my veins and my hand reaches confidently for the right ingredients, able to balance taste and texture even without a formal recipe.

"B.B. met R." is a 1950 hit song by a Surinamese artist, Max Woiski, Sr. that extols the role of beans and rice in building community and friendships. The distinctive rhythms and tunes of the Caribbean locate the music and the meal that it describes within a particular geopolitical context, evoking a sense of home and conviviality for all those who sing along.
Ik vraag je voor een keertje te eten bij mij
Je neemt je vrouwtje mee en je kinders er bij
Je krijgt toch geen kalkoen of een vers kievitsei
Maar wat je bij me eet: Zing 't refreintje met mij-
Refrain: B.B. met R. dat is bruine bonen met rijst...
I'll invite you over to come and eat at our home
You'll bring your wife along and your children, too, can come
You won't get any turkey; a fresh plover's egg there won't be
But as to what you will get, come sing the refrain with me
Refrain: B.B. with R., that is brown beans with rice... ${ }^{6}$

Michael W. Twitty (2012) observes that beans and rice is "a dish that tells stories of migration patterns, diverse cultural influences, and places and tastes of memory" (19). There is much to consider here: Is our bodily knowledge a product of our longings, a physical manifestation of desire? Or is it something else, an embodied way of knowing somehow passed through generations, across oceans?

How is it that this dish, so rarely part of our diet, is still so present in my palate? How is it that I can feel this recipe in my body, that my arms know exactly which 
spices to reach for, my hands know just how much to stir? How is it that my tongue knows its way around this dish, and can tell exactly how much of every ingredient to use, without a single measuring spoon to guide the way? Somehow, Surinamese beans and rice have lodged themselves inside my body, located themselves in my viscera. Somehow my body knows the way. (Sonja)

\section{FOOD AND CULTURAL MEMORY}

Food is intimately connected to questions of cultural memory; this is particularly the case for those who have migrated far from 'home.' In such situations, food can serve to anchor individuals within their new culture. Indeed, Julie Locher et al. argue that:

The nostalgic longing and consumption of particular food items sustain one's sense of cultural, familial, and self identity. When we are physically disconnected from a community, a family, or any primary group that defines who we are, our sense of self may become fractured. In these instances, food items intimately linked with one's past may repair such fractures by maintaining a continuity of the self in unfamiliar surroundings" (qtd. in Tye 2010, 192-193; see also Sutton 2001).

But what about the meanings of food in the context of South American plantation economies, founded as they were on forced migrations and the state-sanctioned fracturing of enslaved and indentured selves? Do such arguments still hold water in these instances? How does the palate respond to such ruptures? How does it reimagine itself? What new selves emerge as a result? Nostalgia, longing, and desire must operate differently in such contexts. The emergence of online communities dedicated to sharing Surinamese recipes and food histories ${ }^{7}$ suggests that some, at least, are actively negotiating this complex relationship between intimacy and violence. Virtual communities allow for a collaborative, shared culinary storytelling drawn from written sources, oral histories, and lived experience. But even in such spaces there are no easy answers; the nostalgic story of food and community is inevitably also a story of dispossession and erasure.

\section{ROUGH GRUB: MOLASSES BUNS}

Molasses was among the staple foods that some Newfoundlanders called 'rough grub'. In addition to molasses, rough grub, I have been told, included such staples as: flour, sugar, butter, milk, and coarse salt, which, along with supplies 
for fishing, were often acquired on a barter system that kept fishers perpetually indebted to merchants. What is interesting about this list is that these items make up the ingredient list for molasses buns (with the exception of the spices that are considered optional). What's more, these ingredients would have been staples in my paternal grandmother's pantry even though my grandfather wasn't a full-time fisherman. My mother, who grew up on a different coast of Newfoundland, shared similar sentiments, stating that molasses and flour were always on hand. It makes sense, then, that many dishes considered traditional Newfoundland foodways would include molasses as a main ingredient, despite the fact that the product itself was imported.

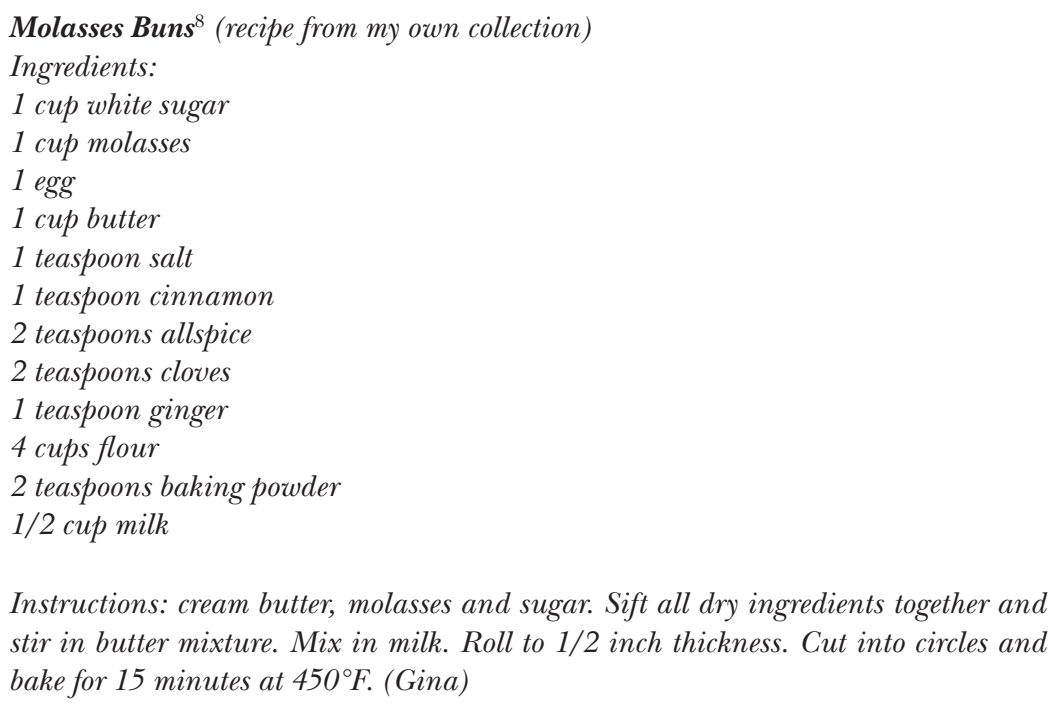

Reading between the lines, this molasses buns recipe reveals an intergenerational story (Tye 2010); that is to say, contained within these lines are the partial life stories of my grandmother, my mother, my aunts, my sisters and, of course, my own. Theophano (2002) contends that, "because cooking is so basic to and entangled in daily life, cookbooks have ... served women as meditations, memoirs, diaries, journals, scrapbooks, and guides" (6). Recipes, therefore, form a kind of collective memory uniting the shared histories and lived experiences of those whose lives touch up against one another in the form of foodmaking and food consumption.

"The lives of a mother and a daughter are inextricably intertwined", writes Caroline B. Brettell (1997, 229). Her claim makes sense to me and I wonder if perhaps 
this is why I feel such an emotional attachment to my grandmother's molasses buns. Could it be that the ways in which my grandmother's life stories are intimately connected to my own life narratives are evident in her baking? What's odd, though, is that now that I am thinking about it I must admit that I have no clear memory of my grandmother making molasses buns. Indeed, I have no specific recollection of being fed molasses buns by my grandmother at all. Despite this, for some reason the thought of molasses buns brings my father's mother to mind. It is conceivable that these memories are embodied in ways that cannot be recalled through conscious memory, but are notable, material, and affective nonetheless. (Gina)

\section{THE FLESH OF TIME}

Sara Ahmed (2015) explains that emotions can tell us a great deal about the world around us and, equally important, our own place within the scope of broader histories. In her words, "emotions are the very 'flesh' of time" (202):

Through emotions, the past persists on the surface of bodies. Emotions show us how histories stay alive, even when they are not consciously remembered; how histories of colonialism, slavery, and violence shape our lives and worlds in the present. The time of emotion is not always about the past, and how it sticks. (Ahmed 2015, 202)

In this sense, my embodied memories of my grandmother's molasses buns conjure pleasant emotions and a sense of belonging.

But molasses is sticky. Viscous, it evokes not only the tangy sweetness of molasses buns; that is, of home, comfort, history, and belonging, but also an unwanted clinging. The viscous, according to Mary Douglas, is a site of abjection:

\footnotetext{
Viscosity repels in its own right, as a primary experience .... The viscous is a state half-way between solid and liquid. It is like a cross-section in a process of change. It is unstable, but it does not flow. It is soft, yielding and compressible. There is no gliding on its surface. Its stickiness is a trap, it clings like a leech; it attacks the boundary between myself and it. Long columns falling off my fingers suggest my own substance flowing into the pool of stickiness ... to touch stickiness is to risk diluting myself into viscosity. (qtd. in Grosz 1994, 194).
}

Sticky, here, is something one cannot escape, no matter how much one wants to. It clings, repels, traps, and attacks, its indefinable form undermining the impermeability of the self. 
Thinking about molasses brings to mind a February afternoon in which we stood in the heat and sun on a former plantation in Suriname while our tour guide told stories of slaves who once tended massive fires while continuously stirring the melting sugar cane as it became liquefied, sticky molasses. (Gina)

It took a team of slaves to make molasses. Stirring the vats was specialized work that required paying careful attention as the liquid transformed from sap into syrup (Beeldsnijder 1994, 142). Other slaves worked to maintain the fire at an even temperature. Another slave, the bosroman, was assigned to brushing crystallized sugar from the sides of the vats.

My family recipes are, thus, implicated in the transnational histories of slavery and colonialism. And, with these stories in mind, the taste of molasses on the tip of my lips seems more bitter than it once did and the taste of salty fish stings the tip of my tongue all the more. No doubt, the sweetness of my childhood memories are disrupted by the messiness of these shared histories. (Gina)

\section{UNSETTLING: A THEORY OF SALT AND SWEET}

Our memory work reveals that we carry within our food stories nostalgic associations with family histories. Our nostalgia allows us to build community, to locate ourselves within larger units; it enables us to imagine home through our palates. In this way, our experiences, memories, longings, and desires reflect common arguments put forward by food studies scholars: food stories are central to our understandings of home and belonging. As Sutton and others have observed, "food is essential to counter tendencies toward fragmentation of experience" (Sutton 2001, 77). If "we become what we eat", as Claude Fischer insists (qtd. in Dawkin 2009, 34), then, it stands to reason that we embody the histories of our culinary traditions. Salty and sweet are the flavours that have shaped our shared culinary palate.

But such nostalgic longings also, as our collaborative memory work has demonstrated, reveal complicated underbellies where our memories must tangle with the realities of colonial violence. Our individual histories and shared journeyings have reshaped our palates, infusing them with different narratives, different histories, different stories. These new stories are unsettling, uncomfortable. Can we taste molasses without thinking of hot vats of boiling sugar cane juice? Can we imagine salt fish without considering the labor of fisherwomen, on the one hand, and enslaved salt pond workers, on the other? Can we imagine either without recalling the colonial violence that has actively sought to erase Indigenous peoples, stories, histories, and palates? 
According to the Oxford English Dictionary Online, to unsettle is "to undo from a fixed position; to unfix, unfasten, loosen"; it is, in this sense, to set something adrift, to separate it from that to which it was previously attached. Such a condition-unsettling-is troubling, disruptive, uncomfortable. To unsettle is "to force out of a settled condition; to deprive of fixity or quiet". What we knew, or, perhaps, what we thought we knew, this definition says, we discover we don't know at all.

What happens when our memories of salt fish are no longer those only of weddings, comfort, winter nights, and family, but instead flavored with the labors of those who produced them and with the transnational histories that made them possible? How might an interrogation of the histories of molasses production unsettle the nostalgia for a Newfoundland culinary ideal? How might our understanding of nationalisms, as articulated through our food memories, be further destabilized by an acknowledgment that all nationalisms erase the presence of Indigenous peoples? What happens when we make food-and when we theorize food-through the "intimacies of four continents" (Lowe 2015); that is, when we acknowledge that "the intimacies of desire, sexuality, marriage, and family are inseparable from the imperial projects of conquest, slavery, labor, and government" (Lowe 17)? Our observational and memory work suggests that foodmaking must be understood within such transnational schemata. It is only through our collaborative autoethnographic work that these encounters have come to the fore: our individual stories are our own; meaning emerges only in the space where our stories meet.

Memories jostle with histories in complicated ways. Our affective engagement with our food stories is troubled, uneasy, unsettled. But perhaps this malaise is necessary. To unsettle, one might argue, is a form of undoing that requires us to make ourselves permeable, to allow ourselves - through our food memories - to become fragmented. It is, as Cixous (1998) would argue, to live in the wound as a site of germination (xiv). To unsettle the palate is to recognize, acknowledge, and indeed claim the complexities embedded in the foods we consume and to acknowledge the violence of enslavement, indenture, and erasure as part and parcel of the intimate longings and nostalgia that we normally associate with food stories and food memories. Intriguingly, to unsettle is also "to clear of settlers"; that is, to undo the premises of the colonial nation-state. This, too, is relevant in relation to food and memory. What does it mean to clear our settler consciousness, and, instead, to locate our palates at the nexus of salty and sweet; to taste the metallic tang of "geographies of blood" (Savage 2012) within the molasses? To unsettle, is to acknowledge, as Claudio Moreira (2009) has observed, that "[t]here is no innocent time, or home for that matter, to look for" (652). 
Contextualized as embodied testimonies, our recipes perform a kind of unsettling, precisely because they call into question hegemonic discourse regarding the ways in which colonialism emerged and persists within the bounds of the distinct yet intertwined geographies of Newfoundland and Suriname. By sharing our entwined testimonies in this manner we perform an act of "collaborative witnessing", which Carolyn Ellis describes as "a form of relational autoethnography that works to evocatively tell the experiences of others in shared storytelling and conversation" (2013, 118). Witnessing, in this sense, can be understood as "a self-reflexive form of solidarity that is always in the process of learning from those who have personally or collectively experienced the violence of imperialism and colonialism" (Emberley 2014, 7). We embody the experiences of our transnational histories as well as the collective trauma inflicted by colonialism and slavery in order to retell those stories through our shared foodways.

Even in winter I am drawn to the call of the sea. I cannot say what, exactly, calls to me but I know for certain that the scent of salt in the air stirs something deep inside me, something that is embedded in the very fiber of my being. Perhaps it is not surprising, then, that even in December I am lured to the edge of the Atlantic Ocean along the coast of Newfoundland. As I wander, tracing the same rocky shore upon which my ancestors have trodden for centuries, it occurs to me that shorelines are, by their very nature, abject spaces. Borderlands, we might say, where saltwater dissolves the boundaries both between land and sea and past and present. My mind wanders, also, back to a February day spent walking along the Suriname River that runs past Paramaribo, merging with the Atlantic Ocean just north of the city. I recall an uneasy feeling that the land and river seemed unwilling to share their stories with me, an outsider. And, yet, I feel a sense of connection in knowing that our stories are intimately entangled. (Gina)

When framed within a postcolonial context, autoethnography insists "that we continue to move through our stories so that we can present them as tools for radical change" (Pathak 2013, 604). According to Marcelo Diversi and Claudio Moreira (2016), embodied testimonies are central to decolonizing practices (586). In a similar manner, Cree scholar Neal McLeod (2007) insists that through storytelling people are better able to understand the world around them and to "question the injustices inflicted upon them" (99). Embodied testimonies, in this context, offer a way to better understand the ongoing legacies of colonialism and slavery that are intimately woven within the fabric of our own family histories. In this sense, we understand our collaborative embodied processes as decolonizing strategies, which, in turn, function as catalysts for social transformation. As Guillermo Gomez-Peña writes, "by decolonizing and 
then re-politicizing our bodies they become sites for activism and embodied theory" (qtd. in Spry 2016, 59). Together, in reading and writing the longings of our palates, we imagine ourselves as "an act of kneading" (Anzaldúa 2007, 103). Our decolonial work can be understood as a reworlding that acknowledges our mutual complicity and embeddedness in a shared history of colonial violence and erasure. Our analysis, founded on a collaborative autoethnographic framework, necessarily complicates any nostalgia we might have felt concerning the familial foodways at the heart of these discussions. Instead, through our shared storying, we implicate ourselves and our families in the very structures that our decolonial approaches aim to critique. Our collaborative autoethnography is both intimate and unsettled, a weaving together of shared stories that resists its telling even as it simultaneously clamours to be heard (Diversi and Moreira 2016, 581).

\section{WORKS CITED}

Ahmed, Sara. "Happy Objects." Ed. Melissa Gregg and Gregory J. Seigworth. The Affect Theory Reader. Durham: Duke UP, 2010. 29-51.

Ahmed, Sara. The Cultural Politics of Emotion. 2nd ed. London: Routledge, 2015.

Alexander, Bryant Keith, Claudio Moreira, and hari stephen kumar. "Resisting (Resistance) Stories: A Tri-autoethnographic Exploration of Father Narratives Across Shades of Difference." Qualitative Inquiry, 18.2 (2012): 121-133. DOI: 10.1177/1077800411429087.

Anderson, Leon. "Analytic Autoethnography." Journal of Contemporary Ethnography 35.4 (2006): 373-395.

Antoniou, Maria. "My Cypriot Cookbook: Re-imagining My Ethnicity." Auto/Biography 12.2 (2004): 126-146. DOI: 10.1191/0967550704ab009oa.

Anzaldúa, Gloria. Borderlands/La Frontera: The New Mestiza. 3rd ed. San Francisco: Aunt Lute, 2007.

Bannister, Jerry. "Making History: Cultural Memory in Twentieth-Century Newfoundland." Newfoundland Studies 18.2 (2002): 175-191.

Beeldsnijder, Ruud. "Om werk van jullie te hebben": Plantageslaven in Suriname, 1730-1750. Utrecht: Utrecht UP, 1994.

Behar, Ruth. The Vulnerable Observer: Anthropology That Breaks Your Heart. Boston: Beacon Press, 1996.

Benjamins, Herman Daniël, and John. F. Snelleman, eds. Encyclopaedie van Nederlandsche WestIndië. Leiden: Martinus Nijhoff; E.J. Brill, 1914-1917.

Berleant, Riva. "Beans, Peas, and Rice in the Eastern Caribbean." Eds. Richard Wilk and Livia Barbosa. Rice and Beans: A Unique Dish in a Hundred Places. Oxford: Berg, 2012. 81-100.

Brettell, Caroline B. "Blurred Genres and Blended Voices: Life History, Biography, Autobiography, and the Auto/Ethnography of Women's Lives." Ed. Deborah E. Reed-Danahay. Auto/Ethnography Rewriting the Self and the Social. Oxford: Berg, 1997. 223-246.

Chang, Heewon. Autoethnography as Method. Walnut Creek: Left Coast Press, 2008.

Chang, Heewon, Ngunjiri Faith Wambura, and Kathy-Ann C. Hernandez. Collaborative Autoethnography. Walnut Creek: Left Coast Press, 2013. 
Chansky, Ricia Anne. "General Introduction." Eds. Ricia Anne Chansky and Emily Hiphen. The Routledge Auto/ Biography Studies Reader. London and New York: Routledge, 2016. xxxxii.

Cixous, Hélène. Stigmata: Escaping Texts. London and New York: Routledge, 1998.

Dawkin, Nicole. "The Hunger for Home: Nostalgic Affect, Embodied Memory and the Sensual Politics of Transnational Foodways." Undergraduate Journal of Anthropology 1 (2009): $33-42$.

Diversi, Marcelo and Claudio Moreira. "Performing Betweener Autoethnographies against Persistent Us/Them Essentializing: Leaning on a Freirean Pedagogy of Hope." Qualitative Inquiry 22.7 (2016): 581-587, doi:10.1177/1077800415617208.

Eakin, Paul John. How Our Lives Become Stories: Making Selves. Ithaca: Cornell UP, 1999.

Ellis, Carolyn. "Heartful Autoethnography." Qualitative Health Research 9.5 (1999): 669-683.

Ellis, Carolyn. The Ethnographic I: A Methodological Novel About Autoethnography. Walnut Creek: Altamira, 2003.

Ellis, Carolyn. "Crossing the Rabbit Hole: Autoethnographic Life Review." Qualitative Inquiry 19.1 (2013): 35-45. DOI: 10.1177/1077800412462981.

Emberley, Julia V. The Testimonial Uncanny: Indigenous Storytelling, Knowledge, and Reparative Practices. Albany: State University of New York, 2014.

Eves, Rosalyn Collings. "A Recipe for Remembrance: Memory and Identity in African-American Women's Cookbooks.” Rhetoric Review 24.3 (2005): 280-297.

Folch, Christine. "Fine Dining: Race in Prerevolution Cuban Cookbooks." Latin American Research Review 43.2 (2008): 205-223.

Grosz, Elizabeth. Volatile Bodies: Toward a Corporeal Feminism. Indianapolis: Indiana UP, 1994.

Halberstam, Jack. Female Masculinity. Durham: Duke UP, 1998.

Heldke, Lisa M. "Foodmaking as a Thoughtful Practice." Eds. Deane W. Curtin and Lisa M. Heldke. Cooking, Eating, Thinking: Transformative Philosophies of Food. Indianapolis: Indiana UP, 1992a. 203-229.

Heldke, Lisa M. "Recipes for Theory Making." Eds. Deane W. Curtin and Lisa M. Heldke. Cooking, Eating, Thinking: Transformative Philosophies of Food. Indianapolis: Indiana UP, 1992b. 251-265.

Hiller, J. K. "James Cook." Heritage Newfoundland and Labrador, 1998. http://www.heritage.nf.ca/articles/exploration/james-cook.php.

Hoogbergen, Wim. Out of Slavery: A Surinamese Roots History. Münster: LIT Verlag, 2008.

Holman-Jones, Stacy, Tony E. Adams, and Carolyn Ellis. eds. Handbook of Autoethnography. Walnut Creek: Left Coast Press, 2013.

Islam, Naheed. "Research as an Act of Betrayal: Researching Race in an Asian Community in Los Angeles." Ed. Alison M. Jaggar. Just Methods: An Interdisciplinary Feminist Reader. Boulder: Paradigm Publishers, 2008. 471-483.

Janzen, Olaf U. "The 'Long' Eighteenth Century, 1697-1815." A Short History of Newfoundland and Labrador, edited by Newfoundland Historical Society, 2008. 49-76.

"K’Taqmkuk Mi'kmaw Cultural Historic Museum," St. George's Indian Band. http://sgib.ca/ index_files/Page1488.htm. Accessed 21 February 2017.

Kovach, Margaret. Indigenous Methodologies: Characteristics, Conversations, and Contexts. Toronto: University of Toronto Press, 2009.

Kuhn, Annette. "Memory texts and memory work: Performances of memory in and with visual media." Memory Studies 3.4 (2010): 298-313. DOI: http://dx.doi. org $/ 10.1177 / 1750698010370034$.

Lowe, Lisa. Intimacies of Four Continents. Durham: Duke UP, 2015. 
McLeod, Neal. Cree Narrative Memory: From Treaties to Contemporary Times. Saskatoon: Purich Publishing Limited, 2007.

Moreira, Claudio. "Unspeakable Transgressions: Indigenous Epistemologies, Ethics, and Decolonizing Academy/Inquiry." Cultural Studies $\Leftrightarrow$ Critical Methodologies 9.5 (2009): 647-660.

Muncey, Tessa. Creating Autoethnographies. Thousand Oaks: SAGE, 2010.

Murray, Hilda Chaulk. More Than 50\%: Woman's Life in a Newfoundland Outport, 1900-1950. St. John's: Flanker Press, 2010.

Nguyen, Vinh. "Mę-search, Hauntings, and Critical Distance." Life Writing 12.4 (2015): 467 477.

Pathak, Archana. "Musings on Postcolonial Autoethnography: Telling the Tale of/through My Life.” Eds. Stacy Holman Jones, Adams, Tony E. and Carolyn Ellis. Handbook of Autoethnography. Left Coast Press Inc., 2013. 595-608.

Pope, Peter E. "Newfoundland and Labrador, 1497-1697." A Short History of Newfoundland and Labrador, edited by Newfoundland Historical Society. St. John's: Newfoundland Historical Society, 2008. 23-48.

Porter, Marilyn. "She Was Skipper of the Shore Crew': Notes on the History of the Sexual Division of Labour in Newfoundland." Eds. Carmelita McGrath, Barbara Neis and Marilyn Porter. Their Lives and Times: Women in Newfoundland and Labrador: A Collage. St. John's: Killick Press, 1995. 33-47.

Prince, Mary. The History of Mary Prince, a West Indian Slave. Related by Herself. With a Supplement by the Editor. To Which Is Added, the Narrative of Asa-Asa, a Captured African. 3rd ed. London: F. Westley and A.H. Davis; Waugh \& Innes, 1831.

Protschky, Susie. "The Flavour of History: Food, Family and Subjectivity in two Indo-European Women's Memoirs." The History of the Family 14.4 (2009): 369-385. DOI: 10.1016/j. hisfam.2009.08.006.

Reed-Danahay, Deborah. ed. Auto/Ethnography: Rewriting the Self and the Social. Oxford: Berg, 1997.

Richards-Greaves, Gillian. "Cookup Rice: Guyana's Culinary Dougla and the Performance of Guyanese Identities." Eds. Richard Wilk and Livia Barbosa. Rice and Beans: A Unique Dish in a Hundred Places. Oxford: Berg, 2012. 137-160.

Savage, Candace. A Geography of Blood: Unearthing Memory from a Prairie Landscape. Vancouver: Greystone, 2012.

"Scheepstijdingen," De West-Indiër: dagblad toegewijd aan de belangen van Nederlandsch Guyana, 9 August 1863: 3.

"Scheepstijdingen," Koloniaal Nieuwsblad, 7 March 1870: 2.

Smith, Linda Tuhiwai. Decolonizing Methodologies: Research and Indigenous Peoples. 2nd ed. Zed Books Ltd., 2012.

Smith, Sidonie and Julia Watson. eds. Getting a Life: Everyday Uses of Autobiography. Minneapolis: Minnesota UP, 1996.

Smith, Sidonie and Julia Watson. "Introduction: Situating Subjectivity in Women's Autobiographical Practices." Eds. Sidonie Smith and Julia Watson. Women, Autobiography, Theory: A Reader. Madison: University of Wisconsin Press, 1998. 3-52.

Spry, Tami. "Performing Autoethnography: An Embodied Methodological Praxis." Qualitative Inquiry 7.6 (2001): 706-732.

Spry, Tami. Body, Paper, Stage: Writing and Performing Autoethnography. Walnut Creek: Left Coast Press, 2011.

Spry, Tami. Autoethnography and the Other: Unsettling Power through Utopian Performatives. London and New York: Routledge, 2016.

Stipriaan, Alex van. "July 1, Emancipation Day in Suriname: A Contested 'Lieu de Mémoire', 1863-2003." New West Indian Guide 78.3/4 (2004): 269-304. 
Sutton, David E. Remembrance of Repasts: An Anthropology of Food and Memory. Oxford: Berg, 2001.

Theophano, Janet. Eat My Words: Reading Women's Lives Through the Cookbooks They Wrote. Houndmills: Palgrave, 2002.

Till, Karen E. "Artistic and Activist Memory-work: Approaching Placed-based Practice." Memory Studies 1.1 (2008): 99-113.

Tsalach, Calanit. "Between Silence and Speech: Autoethnography as an Otherness-Resisting Practice." Qualitative Inquiry 19.2 (2013): 71-80.

Tuck, Eve and K. Wayne Yang. "Decolonization is Not a Metaphor." Decolonization: Indigeneity, Education E Society 1.1 (2012): 1-40.

Tuck, Eve and C. Ree. "A Glossary of Haunting." Eds. Stacey Holman Jones, Tony E. Adams, and Carolyn Ellis. Handbook of Autoethnography. Walnut Grove: Left Coast Press, 2013. 639-658.

Twitty, Michael W. "The Transnational Dish of the Motherland: The African Roots of Rice and Beans," Eds. Richard Wilk and Livia Barbosa. Rice and Beans: A Unique Dish in a Hundred Places. Oxford: Berg, 2012. 19-34.

Tye, Diane. Baking as Biography. Montreal and Kingston: McGill-Queen's UP, 2010.

"un'settle, v." OED Online. Oxford: Oxford University Press, December 2016. Web. 14 February 2017.

Vaneker, Karin. “Discovering Pom's Potential.” Ed. Elizabeth Finnis. Reimagining Marginalized Foods. Phoenix: Arizona UP, 2012. 88-108.

Wall, Sarah. "Easier Said Than Done: Writing an Autoethnography." International Journal of Qualitative Methods 7.1 (2008): 38-53.

Wallace, Rick. Merging Fires: Grassroots Peacebuilding Between Indigenous and Non-Indigenous Peoples. Halifax: Fernwood Publishing, 2013.

Wilk, Richard and Livia Barbosa, "A Unique Dish in a Hundred Places." Eds. Richard Wilk and Livia Barbosa. Rice and Beans: A Unique Dish in a Hundred Places. Oxford: Berg, 2012. $1-18$.

Woiski, Sr., Max en zijn La Cubana Orkest. "B.B. met R. is Bruine Bonen met Rijst," Pathé, PA5004, YouTube, https://www.youtube.com/watch?v=PomS8d1c218.

\section{ABOUT THE AUTHORS}

Gina Snooks is a PhD Candidate in Women's Studies and Feminist Research and Transitional Justice and Post-Conflict Reconstruction at Western University (Ontario, Canada). She has research interests in autoethnography, auto/biography, decolonizing trauma work and Indigenous feminist theories.

Sonja Boon is Associate Professor of Gender Studies at Memorial University (Newfoundland and Labrador, Canada). She has research interests in feminist theory, life writing and autoethnography, migration, and memory. She has published in such journals as Cultural Studies ó Critical Methodologies, Life Writing, International Journal of Communication, SubStance, and the Journal of Women's History, among others. Her second monograph, Telling the Flesh: Life Writing, Citizenship, and the Body in the Letters to Samuel Auguste Tissot, appeared in 2015. 


\section{NOTES}

1 Newfoundland is the island portion of the province of Newfoundland and Labrador, which is the easternmost province in the country of Canada.

2 As a way of uniting the intimate and the critical, we have chosen to weave our autoethnographic writing, as developed from our research journals and memory work, together with our more conventional scholarly writing. The autoethnographic passages are in italics.

3 The Bay of Islands is located on the west coast of the island of Newfoundland and encompasses the city of Corner Brook as well as numerous towns located on each side of the bay. Traditionally occupied by Mi'kmaq peoples, the Bay of Islands was mapped by Captain James Cook in 1767 (Hiller 1998).

4 The Mi'kmaq and Beothuk peoples are the Indigenous peoples of the island of Newfoundland; the Innu peoples are the Indigenous peoples of Labrador.

5 Batjauw is the Surinamese term for salt cod.

6 Translation, Sonja Boon.

7 See, for example, the Facebook page titled Het Kookboek van Dubois-Surinaamse recepten en culinaire geschiedenis (The Dubois Cookbook-Surinamese recipes and culinary history), which celebrates both the Groot Surinaams Kookboek, the first Surinamese-authored cookbook (first published by Dubois in 1976) as well as the country's complex culinary history.

8 When I (Gina) asked one of my aunts if she had my grandmother's recipe I was told that my grandmother did not use a recipe and that her 'recipe' was different every time depending on the ingredients she had on hand. 